\title{
A COMPARATIVE STUDY OF FORECLOSURE LAW IN NEW SOUTH WALES, AUSTRALIA AND SOUTH AFRICA
}

\author{
Angus Lloyd Hornigold \\ BA LLB LLM LLD \\ Assistant Professor, Prince Mohammad bin Fahd \\ University, Saudi Arabia \\ Attorney, South Africa and Solicitor, NSW Australia
}

\section{SUMMARY}

In South Africa, there is little authority on the relationship between the credit provider (bank) and the credit receiver (debtor) after a property has been declared executable and sold at an auction by the Sheriff of the Court following the debtor's default on a loan underlying a mortgage bond. The Uniform Rules of Court may shortly be amended in order to allow a reserve price to be set at an auction. However, the bank may still be compelled to buy the property into possession (PIP) in order to preserve the asset so that it protects the interest of both itself and the debtor should this reserve price not be met by third party purchasers. This amendment is therefore unlikely to address the underlying problems that exist when a bank elects to buy a property at an auction. The authority that does exist provides that the banks stand in a different position vis-à-vis the debtor to that of a third party purchaser. Most notably, it provides that the bank has a duty to credit the proceeds of any sale, when the property is sold from its stock of PIPs to the account of the debtor. This appears to be correct, but there should be a sound theoretical foundation for this proposition. What further duties are owed to the debtor by the bank in these circumstances? In order to address this question, certain suggestions are made based on the New South Wales legal position.

\section{$1 \quad$ INTRODUCTION}

This article will consider the relationship between the foreclosing mortgagee and the mortgagor after foreclosure. This will be after the court has declared the property executable and after the sale has occurred. The focus will be on the relationship between the parties in those circumstances where a foreclosing bank has purchased the property at a sale in execution.

The case law that has considered this part of the relationship will be examined and certain proposals will be put forward that provide a legal basis for regulating that relationship. These proposals will be based on certain mechanisms that exist in the New South Wales, Australian law. 


\section{THE POST-EXECUTION RELATIONSHIP}

In the matter of Bisnath $v$ Absa Bank $L t d,{ }^{1}$ the court was called upon to adjudicate a matter involving a property owned by the Gita Family Trust $^{2}$ of whom $\mathrm{Mr}$ and Mrs Bisnath were trustees.

The Trust fell into arrears with its financial obligations as specified in the loan agreements that were secured by the mortgage bonds. The Bank issued summons against the Trust to recover the monies owed by the Trust. On 8 December 1998, the Bank obtained a default judgment against the Trust and an order was granted declaring the property executable.

The Trust property was sold in execution on 4 October 2000 and purchased by the execution creditor, Absa Bank. Thereafter, it was sold in February 2002 by Absa Bank to Mr and Mrs Durga. ${ }^{3}$ Various disputes arose between the parties one of which related to the right of the bank to retain the proceeds of the sale to the Durgas and not to credit this amount to the account of Mr and Mrs Bisnath. The matter was initially heard in the Durban and Coast Local Division but later went on appeal to the Supreme Court of Appeals. ${ }^{4}$ Importantly, the aspect relating to the banks' obligation to credit the Bisnath's account did not form part of the appeal. It therefore, appears that the bank accepted the correctness of the decision in that regard.

This case is an example of a general practice where, in certain instances, a mortgagee bank may elect to purchase the immovable property at a sale in execution.

Generally, in foreclosure law when a consumer defaults upon an underlying loan agreement the execution creditor, usually a bank in these cases, ${ }^{5}$ is entitled to approach the court for an order declaring the property executable. The mortgaged property will then be sold in execution by the sheriff of the appropriate court:

- In terms of Rossouw v First Rand Bank Ltd t/a FNB Homeloans ${ }^{6}$ (formerly First Rand Bank of South Africa Ltd), if the bank does realise enough at the sale in execution, then it does not lose its right to collect on the balance due under the loan agreement.

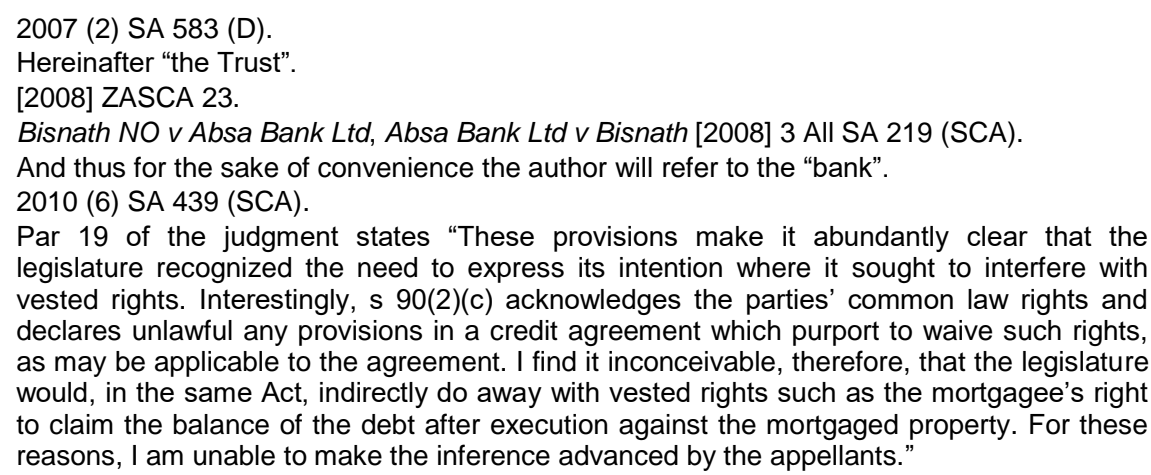

Par 19 of the judgment states "These provisions make it abundantly clear that the legislature recognized the need to express its intention where it sought to interfere with vested rights. Interestingly, s 90(2)(c) acknowledges the parties' common law rights and declares unlawful any provisions in a credit agreement which purport to waive such rights, as may be applicable to the agreement. I find it inconceivable, therefore, that the legislature would, in the same Act, indirectly do away with vested rights such as the mortgagee's right to claim the balance of the debt after execution against the mortgaged property. For these reasons, I am unable to make the inference advanced by the appellants." 
- The bank is not entitled to place a reserve price on the sale when it sells the mortgaged property in execution. ${ }^{8}$

- At the sale in execution, always an auction, the property must be sold to the highest bidder. ${ }^{9}$

- If the sale realises more than the outstanding loan, then the balance, as required by the law, must be refunded to the debtor. If an amount of less than the outstanding loan amount is realised then the debtor is liable for the balance. ${ }^{10}$

The following is usually what happens in practice after the property has been declared executable:

- The bank sends a valuer to the property in order to ascertain its value.

- It decides on a notional reserve price.

- At the auction the bank has its agent, usually the attorney acting for the bank, bid up to the notional reserve price. If there are no higher bidders at the auction, the bank buys the property into its stock of foreclosed housing.

- If it buys the property into its stock of foreclosed housing, it will hold the property as a "property-in-possession" (PIP) and will later sell it on the open market when it receives a price it deems sufficient to offset its losses on the loan upon which the consumer defaulted.

- The consumer will, however, still be indebted by the original shortfall on the loan, that being the difference between the amount received by the bank from the sale in execution and the amount still outstanding.

- The bank will now be the owner of the property and can deal with it as such.

The relationship between the consumer and the bank in relation to the PIP is coloured by a number of important factors:

- Prior to the granting of a mortgage loan, it is customary for the bank to have the mortgaged property valued. This valuation is generally confidential and this information is held by the bank. ${ }^{12}$ Furthermore, the

8 See draft amendments to Rule 46(12) Rules Regulating the Conduct of the Proceedings of the Several Provincial and Local Divisions of the High Court of South Africa (hereinafter "Uniform Rules of Court") http://juta.co.za/law/media/filestore/2014/02/Draft_Uniform Mag_Crt_Rules_amendment.pdf (accessed 2016-11-16). These draft amendments will not solve the problem of the bank having to purchase the asset in order to preserve it. Should the property deteriorate due to non-realisation of the reserve price both parties will be prejudiced.

9 See Rule 46(10) Uniform Rules of Court.

10 See Rule 46(14) Uniform Rules of Court.

11 See eg, a list of the properties in possession held by First National Bank http://www. privateproperty.co.za/fnb-repossessed-houses-and-property.htm (First Rand Bank Limited).

12 See eg, the clause 3.11 of the special terms and conditions of First Rand Bank Ltd https://www.google.com/url?sa $=$ t\&rct $=j \& q=\& e s r c=s \&$ source $=$ web\& $c d=1 \&$ cad $=$ rja\&uact $=8 \& \mathrm{v}$ ed=0ahUKEwjsvlaE64bOAhVBshQKHRB8BZEQFgggMAA\&url=https\%3A\%2F\%2Fwww.fn b.co.za\%2Fdownloads\%2FHomeloans\%2FSpecial_Terms_and_Conditions.pdf\&usg=AFQj CNGz8-M8T5wkrZ5agxvnb-P_b9Txag (accessed 2016-07-22). 
general practice of the larger banks is to have a detailed economic analysis of the property market conducted on a regular basis. ${ }^{13}$ Thus, it is submitted that where the mortgagee is one of the large South African banks, it will have special knowledge about the value of the mortgaged property at the time of execution.

- When a bank elects to purchase a property, which it holds as security for a loan, it is not acting like other market participants. Other participants may be purchasing a home or may be property speculators who seek to buy below market value and then sell the property for a profit or they may be investors seeking to buy and rent the property. The bank buys the property because an underlying loan agreement exists and it is seeking to protect the value of the security. In other words, it is intervening in the normal market processes because it has formed a view that the sale of the securing asset is not realising an optimal amount. The reasons for this could be manifold. For example, insufficient interest on the day, poor short-term market conditions or collusion amongst bidding groups.

- The bank, thus interferes with the market processes in order to preserve the asset as security for the underlying loan. Its decision is based upon an interest in preserving the underlying security for the loan and is premised upon its special knowledge of both the property in question and the market. This arises from both its dominant position in the market and the particular debtor-creditor relationship with the consumer.

- The bank will only intervene to purchase the asset in order to preserve it where the price at the auction is less than the amount due in terms of the loan agreement. Thus, the legal relationship between the two parties continues after the sale in execution.

- The law seeks to ensure that the relationship between credit providers and consumers is fair, transparent and protects consumers. ${ }^{14}$ This is done, inter alia, by balancing the respective rights and responsibilities of credit providers and consumers. ${ }^{15}$

It will be argued that in these circumstances a legal duty is owed to the consumer by the bank in its dealings with the immovable property after the bank has purchased it in possession.

\section{THE MORTGAGEE BECOMES UNQUALIFIED OWNER}

It is a trite law that the bank buying a property at a sale in execution, and subsequently taking transfer thereof, becomes the owner of the property. It, therefore, acquires the right to evict the erstwhile mortgagor/owner. In the matter of Red Stripe Trading $68 \mathrm{CC} v$ Khumalo, $^{16}$ the court was required to

13 See eg, http://propertywheel.co.za/wp-content/uploads/2016/08/HPI-Jul-2016.pdf (accessed 2016-11-16).

$14 \mathrm{~S} 3$ of the National Credit Act 34 of 2005.

15 S 3(d) of the National Credit Act 34 of 2005.

16 [2005] ZAGPHC 31. 
decide upon the right of a mortgagee buying property into stock to evict the erstwhile mortgagor. The court held that the landowner has the right to evict an unlawful occupier subject to a determination of whether it is just and equitable to evict the unlawful occupier and under what conditions it is the right.

The bank becomes the owner of the property following the transfer of ownership in the Deeds Registries Act. It is entitled to exercise all the normal powers of an owner including the right to evict the erstwhile mortgagor. ${ }^{1{ }^{1}}$

Therefore, prima facie, it appears that the bank should be considered an owner no different from that of any third party purchaser of a property at a sale in execution.

However, the KZN court in the Bisnath decision has caused that assumption to be questioned. The court held in that matter that:

"The mortgagee is entitled to 'buy in' the property at a sale in execution and can set off the amount due under the bond against the purchase price. (See Smiles' Trustee $v$ Smiles 1913 CPD 739.) If this is insufficient to satisfy the amount due under the bond, the mortgagee still has a claim against the mortgagor for the balance. Where there is a balance outstanding, the mortgagee is obliged in my view to credit the proceeds of a subsequent sale of the property to the mortgagor's account..."

The court then went further and held that "consequently, after the sale in execution the mortgage bond remains in place and the mortgagee retains his status as such".

It is this statement of the law and its implications, which form the subject matter of this research.

As authority for its view, the court relied on Smiles Trustees $v$ Smiles ${ }^{21}$ and on a dictum in the matter of Syfrets Bank Ltd $v$ Sheriff of the Supreme Court, Durban Central; Schoerie NO v Syfrets Bank Ltd. ${ }^{22}$

In the matter of Smiles Trustees, a trustee instituted an action against the wife of an insolvent. The wife held two mortgage bonds totalling 225 pounds but was also the purchaser of the property at an auction sale by the sheriff. The question in that matter was whether the amount owed to the bondholder could be set off against the purchase price. The court held that the two amounts should be set off against one another and that the wife would owe only the difference between the sale price and the amount owed under the bond.

Thus, this case did provide authority for the general proposition relied upon by the court in the Bisnath matter that the mortgage bond survives the sale in execution.

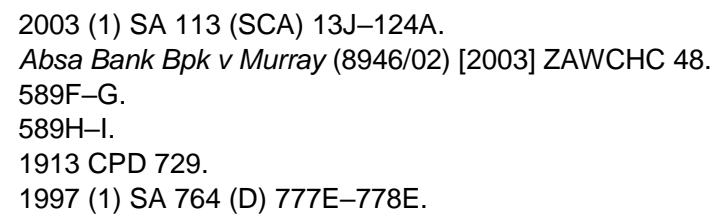


The decision of Syfrets Bank Ltd $v$ Sheriff of the Supreme Court, Durban Central; Schoerie NO v Syfrets Bank Ltd concerned the sale of a property in execution by a mortgagee and subsequently purchased at the sheriff sale by the mortgagee. In that matter, the debtor company was liquidated after the sale in execution but before the transfer of the property. The court held that the liquidation of the company caused the mortgaged property to be vested in the trustee and that the liquidator had the discretion to continue with the sale or to repudiate it. This case, therefore, does not offer authority for the proposition put forward by the court in the Bisnath matter.

The court a quo in Bisnath held that the mortgage bond remains in place after the transfer of the ownership to the mortgagee in the case of a PIP and that the property was held in a manner analogous to a pledge. Furthermore, that the subsequent sale by the bank from its stock of PIPs was analogous to pactum commisorium and the bank was duty bound to credit the amounts received from the sale from the PIP to the account of the mortgagor. ${ }^{23}$ Thus, the bank was not truly acting as a fully independent owner of the property.

The question, which this article seeks to address, is whether this statement reflects the practice in the offices of the Registrar of Deeds in South Africa.

\section{THE RESEARCH QUESTION}

The writer put the following research questions to each of the deeds offices in South Africa:

(1) Does the registrar of deeds cancel the existing mortgage bond when a mortgagee takes transfer of immovable property pursuant to a sale in execution of the mortgaged property following the mortgagor's failure to service the underlying debt?

(2) In the above circumstances does the mortgagee bank become the owner of the property free of any encumbrances following the transfer of the property from the sheriff to the mortgagee or is there a limitation recorded on the title deed of the property?

(3) If the mortgage bond is not cancelled what happens to the mortgage bond?

(4) Is there a practice note that details the practice in the above matters?

Three of the Registrars of Deeds replied.

The answers, which they provided, were substantially similar. They referred to section 56(1) of the Deeds Registries Act ${ }^{24}$, which provides that:

"no transfer of mortgaged land shall be attested or executed by the registrar, and no cession of a mortgaged lease of immovable property, or of any mortgaged real right in land, shall be registered until the bond has been cancelled or the land, lease or right has been released from the operation of the bond with the consent in writing of the holder thereof or unless, in the case

23 590A-D.

24 Deeds Registries Act 47 of 1937. 
of any such mortgage bond which has been lost or destroyed, the registrar has on application by the registered holder thereof, cancelled the registry duplicate of such bond: Provided that no such cancellation or release shall be necessary if the transfer or cession is made (a) in execution of the judgment of any court (including a magistrate's court) by the competent officer."

The Registrars stated that the consent of the mortgagee is generally required for the cancellation of a mortgage bond. This cancellation is necessary prior to the registration of transfer of ownership. However, in the case of a judicial sale in execution, the mortgage bond is cancelled by process of law and no consent is required by the mortgagee. The transferee thus becomes the owner of the immovable property subject to all preexisting encumbrances, such as servitudes, but the property is no longer subject to the mortgage bond. All transferees take free of the mortgage bond regardless of whether the transferee is the prior mortgagee or an independent third party.

Thus, according to the Registrars, the reasoning in the Bisnath matter was incorrect. The property in question is transferred free of the mortgage bond regardless of the identity of the transferee. There is no difference between a mortgagee bank transferee and an independent third party transferee. The court's reasoning is supported neither by the authority upon which it relied nor by any deeds office practice. The Deeds Registries Act $^{25}$ also states the law to be the opposite of that held by the court.

It is submitted, however, that this should not be the end of the enquiry.

\section{WAS THE BISNATH CONCLUSION CORRECT?}

If the bank is the legal owner of the unencumbered property and with no duty to account for its post-execution dealings with it, then it is possible that if a bank sells the property, it may retain all the proceeds of the sale and also collect the balance of the loan from the consumer. Thus, it is possible for the following to occur:

- The loan amount is R1 000000,00 .

- The bank values the property at R1 500 000,00.

- The bank buys it in at an auction due to insufficient interest from bidders at $\mathrm{R} 1,00$. This one rand would be paid by the bank, as purchaser at the sale in execution, to the Sheriff of the Court who would then pay it back to the bank as execution creditor and charge the bank for the costs of execution. These costs in execution would also be for the account of the debtor.

- The consumer is thus indebted to the bank in a sum of R 999999,00 plus all attendant costs.

- The bank then holds the property as a property-in-possession (PIP).

- The bank will sell the house as a PIP and collect R1 500 000,00 when selling it on the open market.

25 Ibid. 
- The bank then also collects from the consumer the R999 999,00 plus all attendant costs.

- Furthermore, whilst holding the PIP, the bank collects rentals on the property by renting it on the open market, which is not credited to the consumer's account.

- The bank may, at its discretion, credit the consumer's account with the amount outstanding and simply keep the difference between what is due and the amount realised by the PIP sale, being the sum of approximately R500 000,00.

- Furthermore, whilst the bank is in possession, the benefits accruing to the bank, for example, income by way of leasing, accrues to the benefit of the bank and not to the benefit of the consumer.

The exact details are not made clear from the Bisnath matter but something of this nature appears to have occurred. The above scenario prima facie seems unfair because the bank not only has obtained a significant profit from the transaction but the debtor has also been significantly prejudiced. Prejudiced because the security for the debt clearly has a value but if, on the day of the auction, there is insufficient interest in the property the sale price will be low. The very reason that the bank is buying the property into its stock of PIPs is because it has taken the view that the sale price is too low. It is able to do this because of its intimate knowledge of the market, intimate knowledge of the property as well as its dominant financial position. The bank is seeking to protect itself against loss.

It is important to consider the reasons that the bank is buying it into stock. This differs significantly from a reserve price, even if it were possible to set a reserve price. A reserve price would have the effect that if the desired price was not obtained at the sale then the sale would be postponed. During this period of postponement, the bank's loss and the debt of the consumer are both increasing. Furthermore, it is possible that the security may deteriorate. It is therefore desirable that the bank takes possession of the asset and that it preserves it until such time as the market conditions have improved.

However, if the decision in Bisnath was accepted as correct without further reflection, the following questions arise:

- If the bank sells the property for more than the amount outstanding on the underlying debt, who is entitled to the profit? The Bisnath decision appears to settle this question. However, as noted above Bisnath is without a sound theoretical footing and is prima facie incorrect.

- If the bank elects to demolish the home and erect a different structure on the land, which it then uses for corporate purposes, how is the consumer protected?

- What if the bank chooses never to sell the house but instead allows it to degenerate and fall into ruin?

- What if the bank chooses never to sell the house but instead chooses to rent it to a third party? 
- What if the bank chooses never to sell the house but instead chooses to allow employees to stay in it free of charge?

- What if the bank chooses to sell the house but has to expend a large sum of money on repairing it. What if these costs of repair exceed the price obtained by the bank?

- What if the bank sells it at a vastly discounted price to a well-connected insider? Who will be responsible for this loss to the consumer?

- Is the sale of the property from the stock of PIPs to be equated in some manner to a pactum commisorrium provision? ${ }^{26}$

It is submitted that the decision of the court may be correct insofar as the treatment of the proceeds is concerned but that an alternate basis needs to be found to support the decision and to provide answers to the above questions.

The bank appeared to have accepted that the decision of the court a quo was correct because it did not appeal that part of the decision.

The writer would submit that the one possible theoretical basis for regulating the post-execution relationship would be that the bank holds the property in a fiduciary capacity.

\section{BUILDING A MODEL FOR POST-FORECLOSURE RULES WHERE THE BANK PURCHASES AT AN AUCTION}

It is submitted that in the absence of legislative amendments, which may become necessary, one possible basis for building a legal model that will govern the relationship between the bank and consumer in this context is that of the fiduciary relationship.

South African courts have imported the principles of fiduciary duty from the English law of equity. ${ }^{27}$ The existence of a fiduciary duty and its scope are to be determined by the facts of the case and the nature of the relationship between the parties. ${ }^{28}$

There are no numerus clausus of relationships that give rise to a fiduciary duty. ${ }^{29}$ However, in the common law, certain relationships have been recognised as giving rise to this duty. These would include, amongst others, agent and principal $;{ }^{30}$ company directors $;{ }^{31}$ doctor and patient; ${ }^{32}$ employee ${ }^{33}$ and employer; ${ }^{34}$ financial adviser and client; ${ }^{35}$ guardian and ward; ${ }^{36}$ lawyer

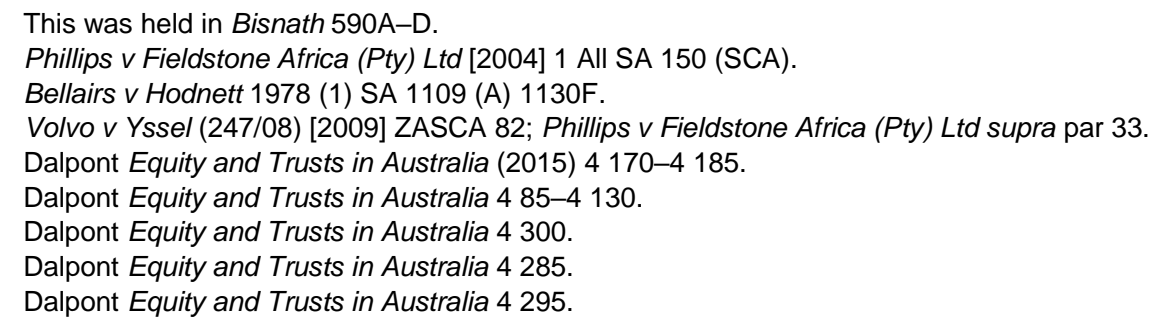


and client; ${ }^{37}$ parent and child $;{ }^{38}$ partners $;{ }^{39}$ real estate agent and client; ${ }^{40}$ trustee and beneficiary ${ }^{41}$ and banker and customer. ${ }^{42}$

In Volvo $v$ Yssel, ${ }^{43}$ the court held that whether a particular relationship is to be regarded in law as a one of trust, depends upon the facts of the particular case. It further held that there are certain characteristics of a relationship that indicates that such a relationship exists. The court quoted with approval from Hodgkinson $v \operatorname{Simm},{ }^{44}$ where it was held that:

"situations in which fiduciary obligations, though not innate to a given relationship, arise as a matter of fact out of the specific circumstances of that particular relationship:

In these cases, the question to ask is whether, given all the surrounding circumstances, one party could reasonably have expected that the other party would act in the former's best interests with respect to the subject-matter at issue. Discretion, influence, vulnerability and trust were mentioned as nonexhaustive examples of evidential factors to be considered in making this determination."

The relationship between banker and client can, in certain circumstances, give rise to a fiduciary relationship. This was expressed obiter in Volvo $v$ Yssel ${ }^{45}$ when it quoted with approval from the American case of Dolton $v$ Capitol Federal Sav. and Loan Ass'n. ${ }^{46}$ This principle is also established in Australia.

The court in Volvo $v$ Ysse ${ }^{48}$ further quoted with approval from Hodgkinson $v$ Simms where the Supreme Court of Canada held that:

"situations in which fiduciary obligations, though not innate to a given relationship, arise as a matter of fact out of the specific circumstances of that particular relationship:

In these cases, the question to ask is whether, given all the surrounding circumstances, one party could reasonably have expected that the other party would act in the former's best interests with respect to the subject-matter at issue. Discretion, influence, vulnerability and trust were mentioned as nonexhaustive examples of evidential factors to be considered in making this determination.

Where one man stands to another in a position of confidence involving a duty to protect the interests of that other, he is not allowed to make a secret profit at the other's expense or place himself in a position where his interests

Dalpont Equity and Trusts in Australia 4 235-4 245.

Dalpont Equity and Trusts in Australia 4315.

Dalpont Equity and Trusts in Australia 4 135-4 165.

Dalpont Equity and Trusts in Australia 4305.

Dalpont Equity and Trusts in Australia 4190.

Dalpont Equity and Trusts in Australia 4175.

Dalpont Equity and Trusts in Australia 480.

Dalpont Equity and Trusts in Australia 4 250-4 260.

Supra par 16.

(1995) 117 DLR (4th) 161 176f-177b.

Supra.

642 p 2d 21 (Colo. App. 1982).

Commonwealth Bank of Australia v Smith (1991) 102 ALR 453.

Supra par 16. 
conflict with his duty. The principle underlies an extensive field of legal relationship. A guardian to his ward, a solicitor to his client, an agent to his principal, afford examples of persons occupying such a position. As was pointed out in The Aberdeen Railway Company v Blaikie Bros. (1 Macqueen 474), the doctrine is to be found in the civil law (Digest 18.1.34.7), and must of necessity form part of every civilised system of jurisprudence."

In the matter of Phillips $v$ Fieldstone Africa (Pty) $L t d,{ }^{49}$ the court approved this approach in dealing with matters of the agency.

It is submitted that these principles are equally applicable in the context of PIPs. The four principles that are to be applied are:

- The facts and circumstances must be carefully examined to see whether a fiduciary relationship exists.

- Once it is established that there is such a relationship, that relationship must be examined to see what duties are thereby imposed on the banker.

- Having defined the scope of those duties, one must see whether the banker has committed some breach thereof by placing himself in a position where his duty and interest conflict. It is only at this stage that any question of accountability arises.

- Finally, having established accountability it renders the banker accountable for profits made within the scope and ambit of his duty. PIPs.

Each of the above questions will be addressed separately in relation to

\section{THE EXISTENCE OF A FIDUCIARY RELATIONSHIP}

The court is obliged to examine all the facts, and circumstances must be carefully examined to see whether a fiduciary relationship exists.

The factors mentioned in the section of this article entitled "The Execution Process" refer to the market dominance and special knowledge of the mortgagee and special relationship of the two parties. It is submitted that these factors support the conclusion that the parties have a fiduciary relationship.

This, it is submitted, leads to the conclusion that the bank is not holding the property in the same way as other market participants. It is holding it in a fiduciary capacity duty bound to the mortgagor to account for all profits.

It is submitted that there are two broad important duties imposed on the bank. The first of these is the no-profit rule and the second is the no conflict rule.

"The fiduciary standard is encapsulated in two principal duties: the 'no conflict' and the 'no profit' duties. The former prohibits a fiduciary, except with the informed consent of the principal, from placing herself or himself in a position involving a real and sensible possibility of a conflict between the duty as a

49 Par 31 and 32.

50 Par 31. 
fiduciary and her or his own interest (a 'duty-interest conflict'), or between the duty as a fiduciary to two or more persons (a 'duty-duty conflict'). The 'noprofit' duty prohibits a fiduciary from making a profit or benefit or exploiting an opportunity arising, out of a fiduciary position except with the principal's informed consent. The duties in question can, and not infrequently will intersect; for instance, a breach of the 'no profit' duty may reflect a yielding to a conflict. A contravention of either duty, in any case, speaks of disloyalty."

Once it is established that a fiduciary relationship exists, it must be determined what obligations are imposed on the bank and what rights the bank would retain.

For the sake of clarity, the foreclosure process in Australia is not governed by the fiduciary relationship even though there is a duty to account and to preserve the property. It has its own common law and legislative basis. It is being argued that in South Africa an appropriate basis for governing the post-execution relationship may be the law relating to fiduciaries. The Australian foreclosure law is being relied upon to give some content to the fiduciary duty.

\section{WHAT DUTIES ARE IMPOSED AND WHAT RIGHTS ARE GRANTED}

During the foreclosure process in Australia, the creditor has a right to take possession of the mortgaged property and is obliged to account for any proceeds received from the property. ${ }^{52}$ The mortgagee is also liable to the mortgagor for any unnecessary injury to the value of the property whilst the mortgagee is in possession, either by a deliberate act of the mortgagee or its agents or by the gross and wilful negligence of the mortgagee. ${ }^{53}$

In this regard, the bank is at liberty to exercise the rights mentioned hereunder in order to preserve the asset and maximise the return thereon, provided that the net financial benefits are credited to the consumer. ${ }^{54}$

The concept of "entering into possession" is not known in South African law. A study of the Australian position may be useful to guide the development of the South African law.

Prior to considering the Australian position, it will be useful to clarify and consider the concepts of foreclosure and receivership.

\section{FORECLOSURE}

Foreclosure in the English common law tradition, and in Australia, differs significantly from the South African position. In essence, the lender becomes the owner through a legal process, which does not entail an auction sale.

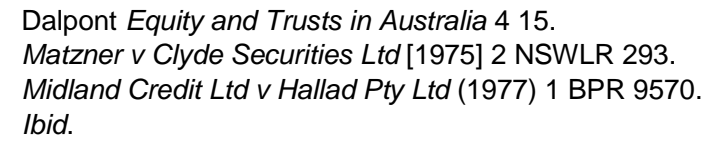


More importantly, the lender loses the right to claim the balance due under the loan. ${ }^{55}$

This process is not alien to the Roman law tradition. In early Roman law the creditor acquired the right to possess the mortgaged security and to sell the property once the secured debt had fallen due. By the time of Justinian, the parties could also agree in a lex commissoria, or "forfeiture clause", that if the debt was not paid by a certain date the creditor would become the owner of the property. This was known as foreclosure.

"In $230 \mathrm{AD}$, a new kind of foreclosure, called impetratio dominii, was introduced whereby the creditor could apply to the court to have ownership granted to him. The property was valued and, upon notice to the debtor and after the lapse of one year, the creditor became bonitary owner of the pledged property. If the property was worth less than the amount of the debt, the debtor was discharged from liability but, if it was worth more, the creditor had to pay the difference to the debtor."

"Justinian permitted foreclosure only where no purchaser, for an adequate price, could be found. If the debtor and creditor lived in the same province, the creditor was obliged to give formal notice to the debtor once two years had elapsed since the debt became due. If they lived in different provinces, the creditor had to apply to the provincial judge who would serve a notice on the debtor, setting a date for payment to occur. Once that date passed without the debt having been paid, the creditor could obtain ownership on petition to the emperor.

Therefore, it is submitted that there may well be scope for the development in our law of a principle that where the lender has entered into possession through the process of acquisition through the judicial sale process. Therefore, one suggestion is that it may be possible for the balance of the indebtedness to be removed if the lender remains in possession for a certain period.

\section{RECEIVERSHIP}

The origin of the concept of a master who assists the court stems from the fourteenth and fifteenth century England. In the equity procedure that developed under the Chancery system, Masters in Chancery assisted the Chancellor in the dispensation of equity functions. Their functions were initially to draw up writs, affidavits and certification of deeds. The equity procedures under the Chancery were introduced to provide remedies where the rigid English common law failed to do so. The purpose of the equity jurisdiction was to protect the poor and the defenceless.

The South African law contemplates the appointment of officers of the court to carry out certain functions of the court. Examples of these include

55 See below.

56 Steyn Statutory Regulation of Forced Sale of the Home in South Africa (Doctoral Thesis) http://repository.up.ac.za/xmlui/bitstream/handle/2263/28364/02chapter2.pdf?sequence=3\&i sAllowed=y (accessed 2016-11-18) 14.

57 Brakel "Special Masters in Institutional Litigation" 1979 4(3) American Bar Foundation Research Journal 543547. 
trustees of insolvent estates, ${ }^{58}$ partnerships and the estates of persons getting divorced. Receivers are appointed by the court and they are ultimately responsible to the court ${ }^{59}$ for the proper discharge of their duties. ${ }^{60}$

In South Africa, a civil search, seizure, and preservation of evidence procedure exists, which is generally known as an Anton Piller order. ${ }^{61}$ In this process generally, the court orders the sheriff to search for, then seize and preserve $^{62}$ evidence that is material to a matter. It will be employed where the applicant justifiably believes the respondent may destroy the evidence if no order is granted. The importance of this order in this context is the role of the supervising attorney. ${ }^{63}$ As in the case of a liquidator of the estate for division of a partnership or a marriage, the attorney acts as the representative of the court to ensure that its orders are properly carried out: he then files a report at court detailing the manner of the search and seizure, and what documents were collected and handed to the sheriff.

A further example in our law of an office similar to that of a special master is the office of the Family Advocate. The powers and duties of the Family Advocate, according to the Mediation in Certain Divorce Matters Act, ${ }^{64}$ include the power to institute an enquiry in order to furnish the court with a report and recommendation on any matter concerning the welfare of the minor child, to appear at the trial or hearing of any relevant application, to adduce any available evidence and to cross-examine witnesses giving evidence at such trial or hearing of an application. Furthermore, in terms of the Children's Act, ${ }^{65}$ it is compulsory for the parties to attend mediation by the Family Advocate in disputes regarding parental rights and responsibilities concerning children born out of wedlock.

The office of the receiver may be of assistance in the area of foreclosure law in two areas in South Africa. The first is prior to the court declaring the property executable. Currently, there is a duty on the attorney of the

\footnotetext{
Enyati Resources Ltd v Thorne 19842 SA 551 (C) 556.

Which may remove them from office.

Smith The Law of Insolvency 3ed (1988) 200.

Anton Piller KG v Manufacturing Processes Ltd CA [1976] 1 All ER 779.

Vis v Minister of Correctional Services 2013 ZAFSHC 101.

See eg, Consolidated Practice Notes, Western Cape High Court, Cape Town Rule 24:

" 5 The order and the accompanying notice are to be served by the sheriff and the contents explained by the supervising attorney in whose presence and under whose supervision the provisions of the order are to be carried out. The supervising attorney shall ensure that no items are removed from the premises until a list of items to be removed has been prepared, and a copy thereof has been supplied to the applicant's attorney and the person served with the order, if present, and such person has been afforded a reasonable opportunity to check such list. The supervising attorney shall not permit the premises to be subjected to a search for items not appearing on the schedule of listed items referred to in paragraph 2 of the order.

6 The supervising attorney shall file with the registrar, by no later than noon on the day but one preceding the return day of the order, a concise report describing the manner in which the order was complied with. The supervising attorney shall ensure that a copy of his/her report is delivered to applicant's attorney and to respondent (or his/her attorney, if represented)."

$64 \quad 24$ of 1987.

6538 of 2005.
} 
execution creditor to bring a substantial amount of information to the court's attention prior to the court declaring the property executable. ${ }^{66}$ Some of this may be inimical to the interests of the execution creditor, placing the attorney for the execution creditor in the invidious position of having to collect evidence, which is contrary to the interests of his or her client. It would be preferable if an independent party could accomplish this task.

The second would be a role that is similar to the role that they currently play in Australia, that is, they administer the property as an independent third property once the debtor has defaulted. As indicated above, this is not an institution, which is alien to South African law. The court in Bisnath equated the act of buying the property into stock as being similar to the process of a pledgee taking possession of the pledged article. ${ }^{67}$ Under Australian law, it is possible for the bank to "enter into possession". This system is similar to our current informal PIP system. However, the consumer protections built into that system might provide the South African law with some useful guidelines. ${ }^{68}$

\section{NEW SOUTH WALES LAW IN BRIEF}

\section{Background}

New South Wales has two systems of property registration. There is old systems title (OST) which is largely governed by the English common law and the Conveyancing Act 1919 (CA). In many respects, it is similar to the South African system in that it is a system of registration of deeds. Most land is no longer held under this system but under a second system, the Torrens Title System (TTS). This latter system is governed primarily by the Real Property Act ${ }^{69}$ (RPA), the Conveyancing Act ${ }^{70}$ and the common law.

Briefly, the TTS was an attempt to address the shortcomings of the deeds based system. The deeds based system provided for the transfer of title being recorded by deed whereas the Torrens system, developed by Sir Robert Torrens, provided for title by registration. ${ }^{7}$

The TTS has a mortgage system similar to that in South Africa, that is, the mortgagor retains ownership of the property and there is a charge on the property that is registered on the title register. Under the OST, the ownership of the property was transferred to the mortgagee and the mortgagor had a reversionary right to demand re-transfer once the underlying debt had been

\footnotetext{
See for eg, Chapter 10.17 of the Practice Manual of the South Gauteng High Court.

7 Bisnath 590A-D.

68 In the context of foreclosure law the fundamental right to housing and the foreclosure process of a primary residence intersect. See for eg, Standard Bank of South Africa Ltd v Bekker 2011 (6) SA 111 (WCC). S 39 of the Constitution of The Republic of South Africa, 1996 provides that when interpreting the Bill of Rights a court may consider foreign law.

6925 of 1900.

706 of 1919.

71 Jackman and Werren Property Law 2ed (2015) 78.
} 
settled. The right of redemption came to be known as the mortgagor's "equity of redemption".

In New South Wales, there are different types of mortgage under each of the two systems of title, namely, legal mortgages, equitable mortgages of a legal proprietary interest, and equitable mortgage of an equitable proprietary interest. These mortgages feature in both TTS and OST. These distinctions are not relevant in this article. ${ }^{73}$

Furthermore, in the common law system, there is an entire branch of law, which does not form part of the South African system, namely, the law of equity. This will not be considered in any depth and will only be referred to where necessary. The rules of equity apply in both OST and the TTS.

The following rights of mortgagees in New South Wales will be considered:

(1) Right to sue on the personal Covenant (personal enforceable promises).

(2) Right to Possession.

(3) Right to Improve the Property.

(4) Right to Lease.

(5) Right to Assign their interest in the property.

(6) Right to Fixtures.

(7) Power to Appoint a Receiver.

(8) Power of Sale.

(9) Foreclosure.

\section{Right to sue on the personal covenant}

The mortgage operates to secure a loan and therefore the mortgagee may take action for any default under the mortgage contract. This would usually be because the consumer failed to pay the capital and interest but it may be for other reasons as well, such as a failure to maintain the property or causing damage to the property.

Under the common law, the covenant to repay the underlying debt is a personal covenant and does not run with the land, which means that it does not follow the assignment of the mortgage bond. However, the position has been modified by statute and the bond is now always assignable both under the TTS and under the OST. ${ }^{74}$

The right to sue on the personal covenant is commonly utilized with the power of sale but is extinguished when the foreclosure process is employed. ${ }^{75}$

\footnotetext{
Jackman and Werren Property Law 286.

Jackman and Werren Property Law 292.

Butt Land Law (2010) 631-632.

75 S 100 of the Conveyancing Act 1919 (NSW) provides that foreclosure extinguishes right of action for debt and equity of redemption.
} 


\section{Right to possession}

Under OST, the first mortgagee by deed holds the legal estate, albeit that the mortgagor has a right to retain possession until a default occurs. In the matter of Four Maids Limited $v$ Dudley Marshall (Properties) Limited, ${ }^{76}$ it was held that the mortgagee may go into possession before the ink is dry on the mortgage unless the mortgage precludes this. This would apply to a legal or first mortgage. Second mortgages would be considered equitable mortgages and this right would not exist. Where the mortgagee does enter into possession, he has a right to collect the profits and rent but is under a duty to the mortgagor to account for them. He also cannot avoid this responsibility by simply not doing anything, as this is considered wilful default. ${ }^{7}$

While in possession, the mortgagee has a duty to take reasonable care to preserve the property, including stopping vandals and making necessary repairs within limits of income. He would also be obliged to maintain the property to the extent of income. ${ }^{78}$

Under OST, the mortgagor is seen as the tenant of the mortgagee and the mortgagee the landlord. Rental and loan repayments are thus one and the same.

Under TTS, the mortgage is seen as a charge over the land, rather than a conveyance, and therefore there is no title to the land in the hands of the mortgagee. However, there is a statutory right to possession in the event of a breach of the covenant to pay principal or interest. In terms of section 60 of the RPA, the statutory right to possession only arises in the event of a failure to pay principal or interest but not in respect of other breaches.

After taking possession, the mortgagee is entitled to the rents and profits of the land but he is obliged to employ these to reduce the mortgage debt. $\mathrm{He}$ is also liable to account to the mortgagor. The mortgagee is also entitled to receive all expenses properly incurred that are necessary to preserve the security and, if the mortgage grants the power or it is necessary to properly realise the value of the land at sale, the cost of making improvements to the land. $^{80}$

\section{Right to improve the property}

A mortgagee in possession is entitled to spend money preparing and improving the property to ensure the property is in a saleable condition. This is, however, not an unlimited right and there should not be an excessive expenditure. ${ }^{81}$ In the matter of Southwell $v$ Roberts, ${ }^{82}$ the mortgagee in

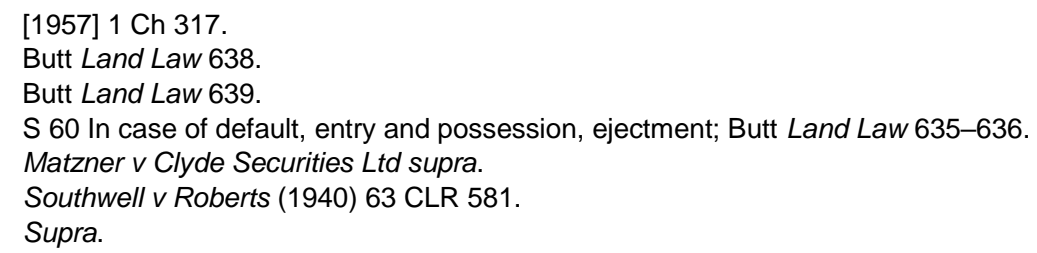


possession determined that the properties had become so dilapidated that it was not possible to economically repair them and accordingly decided to demolish and rebuild the houses. She constructed two semi-detached brick cottages on Portion "A" and a double fronted detached brick bungalow partly on Portion "A" and partly on Portion "B". Dixon J noted that this was very unfortunate for the mortgagee and a windfall for the mortgagor. However, the loss to the mortgagee arose from her, ignoring the mortgagor's position and proceeding to build upon the tacit assumption that she was an absolute owner and not simply a mortgagee in possession of a security for a debt.

In his judgment, Starke $\mathrm{J}$ held that the amount expended was neither reasonable in the amount nor reasonable with regard to the nature of the property. The mortgagee spent double the amount of the principal debt and changed the character of the buildings upon the land. Indeed, on the vacant portion of the land, she erected a building where none had been before. The case is an example of a mortgagee in possession effecting improvements without regard to the mortgagor's interest and calculated to improve him out of his property. In these circumstances, the expenditure was not allowed, unfortunate though it was for the mortgagee. Nevertheless, she could have protected herself by obtaining the consent of the mortgagor or possibly by foreclosing.

Dixon $\mathrm{J}$ held that the disproportionate amount of the expenditure and the alteration in the nature of the premises produced by demolishing the old buildings and erecting new semi-detached cottages on the vacant portion of the land and a single cottage on the site of the former building combined to make it impossible to allow the mortgagee to add the cost to the mortgage monies.

\section{Right to lease}

Under OST, the mortgagee was entitled to grant a lease of the mortgaged property, even where the mortgagee was not in possession because he held the legal estate. However, such a lease cannot bind the mortgagor after redemption as this is regarded as a clog on the equity of redemption. The lease must also be at the best rent available in the circumstances. ${ }^{83}$

Under the TTS, the right to lease only arises once the mortgagee has entered into possession.

\section{Right to assign}

The mortgage of land has two parts, namely the underlying personal debt and the interest in land, which is the security for that debt. ${ }^{85}$ Under OST and in terms of section 91 of the CA, if there is an assignment of the mortgage by

83 In terms of $\mathrm{S} 106$ of the Conveyancing Act 1919 (NSW) a lease of this nature is not to exceed 5 years; will be at the best rent which can reasonably be obtained.

84

Land Law 645.

85 Butt Land Law 631-632. 
way of a registered memorandum endorsed on or annexed to the mortgage" then the personal debt is also assigned. ${ }^{86}$

This is not the case with the assignment of a mortgage under the TTS that allows for an automatic assignment. In terms of section 52 of the RPA, any assignment of the mortgage also serves to assign the personal debt except where the debt is of a collateral nature. ${ }^{87}$

\section{Power to appoint a receiver}

Either the power to appoint a receiver is an express power in the mortgage or it is implied into the contract by legislation. The powers of the receiver will be those that are contained in the mortgage if they are expressed in the mortgage. Where they are not so expressed then the powers of the receiver will be those that are implied into the OST or TTS mortgages by the relevant legislation. The receiver may also be appointed by the court. A receiver can only be appointed once there has been a default.

The duties of the receiver include the following:

1 The receiver is to manage and administer the property in the interests of both the mortgagor and the mortgagee.

$2 \mathrm{He}$ is to preserve the property, which serves as security.

$3 \mathrm{He}$ is to credit any payments received, for example by way of rental, against payments due to the mortgagee.

$4 \mathrm{He}$ is to realise the property, either by way of an auction or by way of private sale.

5 The receiver has a duty to act in good faith and not to sacrifice the mortgagor's interests.

6 He must act within the conditions of his appointment.

7 He must account to the mortgagor for all he has done including any surplus. ${ }^{89}$

\section{Power of sale}

The power to sell may be expressly stated in the mortgage or the law may imply it. Section 109(1) of the CA implies into all mortgages the power to sell without a court order. However, a court has the power to order the sale of a mortgaged property. This may arise in the case of equitable mortgages under certain conditions. The sale may be by private sale or by an auction. ${ }^{90}$

\footnotetext{
Ibid.

Butt Land Law 632.

88 Butt Land Law 647-648.

9 Ibid.

90 Butt Land Law 653.
} 
The mortgagee is entitled to sell to himself by way of a "buy in" at an auction or at a court directed sale. ${ }^{91}$

The mortgagee has certain duties to the mortgagor when exercising this power of sale. It is convenient to divide this into two periods, namely pre- 1 November 2011 and post- 1 November 1977.

Pre-1977, the mortgagor was required to act in good faith, this was something less than a duty not to act negligently. The High Court determined that the mortgagee was required to act "in good faith", that is, an obligation to refrain from acting in wilful or reckless disregard of the interests of the mortgagor. Bryson JA in Commonwealth Bank of Australia $v$ Hadfield ${ }^{92}$ held that:

"[t]o exercise of the power in good faith for the purpose for which it was conferred; the mortgagee cannot act for any extraneous purpose or byemotive, and cannot sacrifice the interest of the mortgagor; to do so would be to depart from good-faith exercise of the power, and from the concept of a sale in the exercise of the power. The sale must bona fide be a sale, not a sacrifice, and the mortgagee cannot be indifferent to the price provided only that its debt is paid. In the pursuit of its own interest the mortgagee is entitled to choose the time at which it sells the property."

A failure to exercise this duty was actionable. The mortgagee could thus not sell the property for a price that was too low. In ANZ Banking Group $v$ Bangadilly Pastoral Co Pty Limited, ${ }^{93}$ Talga Pastoral owned a property called Bangadilly. The property was subject to two mortgages. The first mortgage was to Glenthorne (Pty) Ltd and the second to ANZ Bank. Talga contracted to sell Bangadilly to Hall Investments (Pty) Ltd but this transaction failed to materialise. Hall then arranged for another of their companies, Halco Products, to take an assignment of the 1st mortgage for $\$ 280,000$, this being the principal plus interest. Halco purported to exercise its power of sale and sold the property to a third company controlled by Hall. ANZ sought a declaration that the sale be set aside. The court held that Halco acquired a mortgage by transfer from the first mortgagee at a time when, to its knowledge, the mortgagor was already in default under the mortgage and was in serious financial difficulties. It was evident that from the outset Halco had an intention to utilize its power of sale. It had obtained no profit from the transaction, it had failed to advertise properly, there was only one genuine bidder at the auction and the property realised only $\$ 265,000$, showing an apparent loss to Halco, as the first mortgagee, of some $\$ 15,000$ plus costs and expenses. This left no money for distribution to the second mortgagee, ANZ Bank. The court set the transaction aside.

In Palk v Mortgage Services Funding,$^{94}$ the mortgagor owed more money than the value of the house. The mortgagor wished to sell the property but because of a slump in the property market, the mortgagee declined to allow a sale because of the shortfall. Mrs Palk was not in possession of the

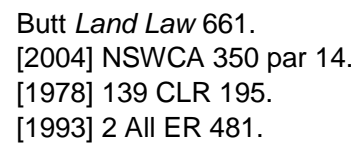


property. The debt that Mrs Palk owed was increasing due to the failure of the mortgagee to take action. The court held that a mortgagee is not obliged to take steps to realise his security. However, he is not permitted to ignore the interests of the mortgagor. If he enters into possession, he cannot simply adopt a supine and an indifferent attitude. He is obliged to act fairly towards the mortgagor. He should not sell in haste at an artificially reduced price. However, if he elects to wait, then he is not permitted to debit the account of Mrs Palk with the rising interest costs.

The period post 1 November 2011 is governed by Section $111 \mathrm{~A}$ of the CA to take all reasonable care to sell the land for not less than its market value. The obvious first step in this process is to ascertain the true market value of the property. ${ }^{95}$ If the mortgagee fails to fulfil its duties, then a mortgagor who suffers loss or damage as a result of the mortgagee's failure has a remedy in damages. This duty would include, where an auction process is employed, setting an appropriate reserve price. ${ }^{96}$

It is of importance to note that the mortgagee has a statutory obligation to account for all monies received in pursuance of the power to sell. Section $58(3)$ of the RPA provides that the monies received are to be distributed as follows:

(i) in the payment of expenses occasioned by the mortgagee's sale (estate agent, advertising etcetera);

(ii) in the payment to the mortgagee of the money due and owing to the mortgagee under the mortgage;

(iii) if any surplus remains, then in the payment to subsequent mortgagees in the order of their priority; and

(iv) if any surplus remains after that, then to the mortgagor.

\section{Foreclosure}

Foreclosure under the Australian system differs significantly from foreclosure under the South African system. In South Africa, the term foreclosure is used in a different sense. Foreclosure is used to describe the process by which a bank executes a judgment secured by way of a mortgage bond against immovable property through the medium of a court order.

The common law system envisages a right of redemption, that is, the right of the mortgagor to claim re-transfer of ownership of the real estate once the mortgage has been settled. Foreclosure extinguished the mortgagor's right to redeem the mortgage, or stated differently, foreclosure extinguishes the equity of redemption. Although this was part of OST, the system has also been carried through to the TTS. ${ }^{98}$

\footnotetext{
Butt Land Law 672.

ANZ Banking Group v Bangadilly Pastoral Co Pty Limited supra.

Absa Bank Limited v Lekuku (32700/2013) [2014] ZAGPJHC 244 par 7.

Jackman and Werren Property Law 293.
} 
In Australia, a foreclosure is only a viable option when the property is worth less than the mortgage liability. There are no other means for the mortgagee to recover the deficiency and the mortgagee is prepared to own (and retain as an investment or develop) the mortgaged property. By following this route, the mortgagee elects to extinguish his interest right to collect any further debt under the loan agreement.

The requirements are as follows:

1 The mortgagor must have defaulted.

2 A valid statutory notice must have been served.

3 There must have been non-compliance with the statutory notice- no payments made.

4 The mortgaged land must have been offered for sale by way of an auction.

5 The highest bid at the auction must have been less than the mortgage debt.

6 The Supreme Court must have made a decree nisi under which an account is taken of the precise mortgage debt and the mortgagor is given a specified time to repay (usually six months).

7 The mortgagor must have failed to repay the mortgage debt within the specified time.

8 The court must have made an order for foreclosure absolute.

9 A foreclosure may be re-opened. ${ }^{99}$

\section{UNCONSCIONABILITY}

One further aspect needs comment and that is the issue of equity. It is not necessary to elaborate in detail on the law of equity but there is a growing argument in the common law communities that the general principle underlying all the law of equity is unconscionability. ${ }^{100}$ It has been held that the principles of equity are being incorporated into South African law. ${ }^{101}$

\section{CONCLUSION: A WAY FORWARD FOR SOUTH AFRICAN FORECLOSURE LAW}

When the bank buys a house into possession it opens the door for possible abuse, that is, the bank makes an undue profit by both selling the house out of possession and collecting the outstanding debt from the consumer and, possibly, collecting rentals whilst in possession. The court in the Bisnath decision employed the incorrect legal mechanism to justify its finding that the execution creditor remains liable to the execution debtor to account for the

99 Butt Land Law 650-652.

100 Sneddon "Unconscionability in Australian Law: Development and Policy Issues" 199214 Loy LA Int'l \& Comp LR 545546.

101 Absa Bank Limited v Lekuku supra par 61. 
proceeds of the sale once it is in possession of the property. It is submitted that developments could be permitted in our law, which recognise the position of trust occupied by the bank when the property, which is security for the loan, is bought in at a judicial auction, but the underlying loan remains unsatisfied. Here are several proposals for possible developments in our law that may better protect the consumer.

The suggestions in broad terms that are based on the Australian law and are as follows:

(1) Recognise that the foreclosing bank is prohibited from acting in a manner, which is unconscionable. This may be a policy tool to prevent certain of the abuses referred to above.

(2) At the time of bringing the application for default judgment and seeking an order, declaring the property to be declared executable the execution creditor would be required to make an election. This election may require justification before the court, which could be informed by way of an expert valuation that is filed before the court. The first option is for the bank to take possession of the house and it is obliged to write off any balance owed by the execution debtor. This would be akin to the Australian type of foreclosure. The second option is that the security is to be sold at a sale in execution.

If it is sold in execution and it subsequently becomes a PIP then it could be legally recognised that the bank has entered into possession. This would be the recognition of the ongoing fiduciary relationship between the bank and the consumer. As a result, the execution creditor would be accountable to the execution debtor. This could include the right to possess the property, the right to improve the property, the right to lease, right to the fixtures and the power to appoint a receiver to deal with the property whilst it is in possession. However, importantly, as in Australia, there would be a full duty to account to the execution debtor for its actions and any income received whether from the sale, rental or other sources. This net income would be for the credit of the consumer. It would be this duty to account and the duty to act in good faith, which would effectively address the concerns of the court in Bisnath.

(3) The appointment of a receiver may operate at two possible junctions in the South African law. The first is prior to the court declaring the property executable. Currently, there is a duty on the attorney of the execution creditor to bring a substantial amount of information to the court's attention prior to the court granting the order of execution. ${ }^{102}$ Some of this may be difficult to obtain or conflict with the interests of the bank. This place the attorney for the execution creditor in the invidious position of having to collect evidence that is contrary to the interests of his or her client. It would be preferable if this task could be accomplished by an independent party.

The second is at the post-execution phase, that is, in a similar phase to which this is employed in Australia. Here the receiver would take

102 See eg, Chapter 10.17 of the Practice Manual of the South Gauteng High Court. 
possession of the property, manage the property until he deems that it is an appropriate time to sell it and then to dispose of it. As an officer of the court, he would ensure that both the interests of the execution creditor and the execution debtor are properly protected and would therefore be required to account for all income and expenses.

(4) Finally, it is submitted, that for the sake of practicality, that if the property is not sold by the bank, from its stock of PIPs, within a certain period that the consumer's debt be written off. 